\title{
Reply to the letter "Is unilateral facial palsy truly caused by SARS-COV-2?"
}

\author{
Resposta à carta "A paralisia facial unilateral é realmente causada pelo SARS-CoV-2?" \\ Bruno Niemeyer de Freitas RIBEIRO', Edson MARCHIORI ${ }^{2}$
}

Initially, we would like to thank Finsterer et al. ${ }^{1}$ for the interest in our article about a 26-year-old man with COVID-19 who developed facial paralysis eight days after the infection started ${ }^{2}$. This allows for a more in-depth debate on the topic and enables the exchange of information and greater knowledge about the neurological manifestations of COVID-19.

Upon carefully reading the letter, we understand that the doubts of Finsterer et al. are based on the fact that not all the investigation carried out on the patient is expressly included in the body of the text. This fact stems from the need to adapt to the publication model (Images in Neurology), which allows a maximum of 100 words. However, with the opportunity given, we can expose more information about the clinical case and present one more neurological manifestation of COVID-19, as well as others widely published in the world literature in major international journals ${ }^{3,4,5,6}$.

With regard to the case presented, the analysis of the cerebrospinal fluid (CSF) showed a slight increase in proteins $(53 \mathrm{mg} / \mathrm{dL})$, with cell and glucose counts within normality parameters, corroborating the findings of other studies which suggest that the involvement of cranial nerves in COVID-19 is not through direct viral action, but through an immune-mediated reaction ${ }^{3}$.

Regarding the differential diagnoses questioned (other viral infections, Borreliosis, sarcoidosis, otitis media, diabetes, nuclear ischemic stroke, trauma, and malignancy), all were excluded through clinical history, laboratory, and imaging tests. Other diagnoses that are more common in our country and not mentioned by Finsterer et al., such as syphilis, were also excluded. The diagnosis of Moebius Syndrome was not considered since this condition clinically manifests during childhood and the abnormality in the facial nerve consists of absence or hypoplasia, a fact completely disposable only by the image presented, with a visible facial nerve and preserved thickness.

The third question asked by Finsterer et al. was about treatment and clinical course. The patient did not need hospitalization or oxygen during COVID-19 pneumonia, being medicated with prednisone and valacyclovir for the treatment of facial palsy, obtaining complete resolution one month after the onset of the treatment.

Regarding the last question, our case did not show significant differences in clinical, laboratory and imaging aspects compared to other studies, but rather similarities, corroborating and reinforcing the neurological manifestations of COVID-19 9 3,4,5,67,8,9.

Certainly new and little-known diseases deserve careful evaluation and are sometimes difficult to accept, mainly associated with the fact that the last pandemic caused by an infectious pathogen (Spanish flu; H1N1) occurred about 100 years ago ${ }^{10}$. Finally, we believe that this discussion adds a lot to the scientific community and we hope that future studies will bring further clarification. 


\section{References}

1. Finsterer J, Scorza FA, Scorza CA, Fiorini AC. Is unilateral facial palsy truly caused by SARS-CoV-2? Arq Neuro-Psiquiatr. 2021 Feb;79(2):183. https://doi.org/10.1590/0004-282X-anp-2020-0519

2. Ribeiro BN, Marchiori E. Facial palsy as a neurological complication of SARS-CoV-2. Arq Neuro-Psiquiatr. 2020 Out;78(10):667. http:// dx.doi.org/10.1590/0004-282x20200127

3. Goh Y, Beh DL, Makmur A, Somani J, Chan AC. Pearls and oy-sters: facial nerve palsy as a neurological manifestation of Covid-19 infection. Neurology. 2020 Aug;95(8):364-7. https://doi.org/10.1212/ WNL.0000000000009863

4. Caamaño DS, Beato RA. Facial diplegia, a possible atypical variant of Guillain-Barré Syndrome as a rare neurological complication of SARS-CoV-2. J Clin Neurosci. 2020 Jul;77:230-2. https://doi. org/10.1016/j.jocn.2020.05.016

5. Ellul MA, Benjamin L, Singh B, Lant S, Michael BD, Easton A, et al. Neurological associations of COVID-19. Lancet Neurol. 2020 Sep;19(9):767-83. https://doi.org/10.1016/S1474-4422(20)30221-0

6. Ahmed UM, Hanif M, Ali MJ, Haider MA, Kherani D, Memon GM, et al. Neurological manifestations of COVID-19 (SARS-CoV-2): a review. Front Neurol. 2020 May;11:518. https://doi.org/10.3389/ fneur.2020.00518

7. Munhoz RP, Pedroso JL, Nascimento FA, Almeida SM, Barsottini OG, Cardoso FE, et al. Neurological complications in patients with SARSCoV-2 infection: a systematic review. Arq Neuro-Psiquiatr. 2020 May;78:290-300. https://doi.org/10.1590/0004-282×20200051

8. Studart-Neto A, Guedes BF, Tuma RL, Camelo Filho AE, Kubota GT, lepsen BD, et al. Neurological consultations and diagnoses in a large, dedicated COVID-19 university hospital. Arq NeuroPsiquiatr. 2020 Aug;78(8):494-500. https://doi.org/10.1590/0004$282 \times 20200089$

9. Lima MA, Silva MTT, Soares CN, Coutinho R, Oliveira HS, Afonso L, et al. Peripheral facial nerve palsy associated with COVID-19. J Neurovirol. 2020 Dec;26(6):941-4. https://doi.org/10.1007/s13365020-00912-6

10. Martini M, Gazzaniga V, Bragazzi NL, Barberis I. The Spanish Influenza Pandemic: a lesson from history 100 years after 1918. J Prev Med Hyg. 2019 Mar;60(1):E64-E67. https://doi. org/10.15167/2421-4248/jpmh2019.60.1.1205 